International Journal of Instruction e-ISSN: 1308-1470 • www.e-iji.net

Article submission code: 20200221160208

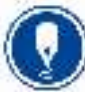

Received: $21 / 02 / 2020$ Revision: 21/08/2020
April 2021 • Vol.14, No.2

p-ISSN: 1694-609X

pp. 11-26

Accepted: 12/09/2020

OnlineFirst: 03/01/2021

\title{
The Effect of Problem Based Learning on Problem Solving and Scientific Writing Skills
}

\section{Yuli Ifana Sari}

Postgraduate student, Geography Education Program, State University of Malang, Indonesia,ifana@unikama.ac.id

\section{Sumarmi}

Prof., Department of Geography, State University of Malang, Indonesia, sumarmi.fis@um.ac.id

\section{Dwiyono Hari Utomo}

Assoc. Prof., Department of Geography, State University of Malang, Indonesia, dwiyono.hari.fis@um.ac.id

\section{Komang Astina}

Ph.D., Department of Geography, State University of Malang, Indonesia, komang.astina.fis@um.ac.id

Scientific writing is essential for students to express their idea and to report their research. Problem-based learning model directs students to solve problems and report them in the form of scientific articles. The report is written logically and systematically. The research used a quasi-experiment method with 62 students as participants. The research was conducted in the Geography Education Program of Kanjuruhan University of Malang, Indonesia, academic year 2017/2018 on the course of Geography Natural Resource. The instruments used were essay tests and assessment rubrics for scientific writing. Data from problem-solving and scientific writing assessments were analysed with the Mann-Whitney test with a significance level of 5\% after a prerequisite test. The results of the study showed that: problembased learning model has a significant effect on students' problem-solving skills, scientific writing skill, and together problem-based learning and problem-solving skills had significant effect scientific writing skill.

Keywords: scientific writing, problem-solving, problem-based learning model, learning, writing

\section{INTRODUCTION}

Students' problem-solving skills should be the focus of improvement. The role of the lecturer in learning is not only as an intermediary to convey concepts related to the 
course but more on improving student skills in solving problems. Problem-solving skills can be obtained through learning steps that direct students to think and find solutions for a problem. Problem-solving is a crucial component of the curriculum and needs attention in learning (Nayazik, 2017; Widiawati et al., 2018).

In the 21st century, human resources can be replaced by technology so that skills possessed by humans now can no longer follow the standards of the past. The use of information and communication technology in all aspects of life requires a change in competencies needed in work (Dwyer et al, 2014; Hidayah et al, 2017). Essential skills that should be mastered by students in the 21 st century are: critical thinking and problem-solving, creativity and innovation, collaboration, and communication (Hosnan, 2014; Redhana, 2019). Lecturers should be selective in choosing learning models that fit the demands of 21st-century skills in the learning process.

The ability to write scientific articles is a skill that must be trained for students. On average, each course demands students to write papers, field research, laboratory research, or books. Writing skills are also needed by students as part of the requirements to obtain a bachelor's degree, namely writing thesis and scientific articles. Writing is also needed for publication to convey the thoughts and ideas of students when they are in college and when they become educators. Through writing skills, students can build strong intellectual and practical relationships between research and independent learning (Wardani \& Sari, 2017; Sutarman et al, 2019). Therefore, students must be equipped with research skills presented in each learning through a model in which there is a syntax of inquiry and report the results in scientific reports/articles. The process of field investigation can stimulate students to find solutions (Alrahlah, 2016; Aliman et al, 2019).

Natural Resource Geography is an auxiliary science in studying geography. The course studies about human interaction with nature concerning the utilization and management of natural resources by humans. The material presented in the Geography of Natural Resources course, especially regarding the management of natural resources, was made the object of study by students observing, investigating, and researching in the field. After investigating the field, students are required to make reports in the form of scientific articles. Students learn to write scientific papers systematically through the task of writing articles (Wardani \& Sari, 2017; Imelda et al, 2019).

The syntax of the Problem Based Learning (PBL) model directs students to think, analyze, research, and prepare research reports. The investigation phase, which is carried out independently or in groups, is the core of the PBL model. Activities undertaken by students in this phase include the process of collecting data, making hypotheses, and providing solutions so that problem-solving skills can be developed and trained. Implementation of research-based learning can improve student metacognition skills in problem-solving (Ashari et al, 2016; Dafik et al, 2019). Lecturers can act as facilitators and motivators for students in gathering information from various sources at the investigation stage.

The next phase of the PBL model is to develop and present the work. The syntax increases the motivation of students to present their work in front of other study groups 
well so that the competence of examining natural resource utilization problems during Natural Resource Geography can be achieved optimally. The PBL can develop complex skills and independence of learning to students (Taradi et al, 2005; Sugiharto et al, 2019). The skills in compiling reports support students to have the ability to convey the results of data acquisition, analysis, conclusions and be able to account for scientific findings in writing so that the ability to write scientific articles can be improved.

This paper aims to describe 1) the effect of problem-based learning model on students' problem-solving skills, 2) the effect of problem-based learning model on students' ability to write scientific articles, and 3) the effect of problem-based learning model and problem-solving skills on the ability to write scientific articles.

\section{LITERATURE REVIEW}

\section{Problem Based Learning (PBL)}

Problem-based learning (PBL) was first implemented in the Medical Faculty of McMaster University in Canada in 1970 (Amir, 2009). The implementation of PBL at McMaster is community-oriented, focused on humans, through an interdisciplinary approach to learning and problem-based learning. Further development, PBL has been adopted either in whole or in part by many medical faculties in the world. PBL is not designed to help lecturers convey information or material as a whole to students. This model is designed to direct students' thinking, problem-solving, and intellectual skills. The habit of critical thinking in Indonesia itself is carried out through learning activities with a scientific approach by conducting scientific investigations (Wahyudi et al, 2015; Fajrianthi et al, 2016; Agraw et al, 2017; Sari et al, 2019).

The implementation of PBL models in Higher Education aims to develop thinking skills, problem-solving skills, and effective self-directed learning. Learning by presenting problems contained in the PBL model syntax can encourage students to develop critical thinking skills and solve problems (Schapper \& Mayson, 2010; Balim et al, 2014; Gholami et al, 2016; Saputra et al, 2018). The process of solving problems in learning requires thinking, analyzing, evaluating, and generating ideas. The steps of the Problem Based Learning (PBL) used in this study are shown in table 1.

Table 1

Syntax of problem based learning (Arends, 2008)

\begin{tabular}{ll}
\hline Phase & Lecturer's Behavior \\
$\begin{array}{l}\text { Phase } 1 \\
\text { Students orientation to the problem }\end{array}$ & $\begin{array}{l}\text { Lecturer explain the purpose of learning and motivate students to } \\
\text { be actively involved in solving the selected problem }\end{array}$ \\
\hline $\begin{array}{l}\text { Phase } 2 \\
\text { Organize students }\end{array}$ & $\begin{array}{l}\text { Lecturer help students organize leaning task related to the } \\
\text { problem. }\end{array}$ \\
\hline $\begin{array}{l}\text { Phase } 3 \\
\text { Individual and group research guide }\end{array}$ & $\begin{array}{l}\text { Lecturer encourage students to gather appropriate information, } \\
\text { carry out experiments, and solve the problem. }\end{array}$ \\
\hline $\begin{array}{l}\text { Phase } 4 \\
\text { Develop and present the work }\end{array}$ & $\begin{array}{l}\text { Lecturer assist students in planning and preparing suitable works } \\
\text { such as reports, models and sharing assignments with friends. }\end{array}$ \\
$\begin{array}{l}\text { Phase 5 } \\
\text { Analyze and evaluate the problem- } \\
\text { solving process }\end{array}$ & \begin{tabular}{l} 
Lecturer help students to reflect on the investigation \\
\hline
\end{tabular} \\
\hline
\end{tabular}


Students' skills in solving problems can be developed through PBL. The learning steps of PBL facilitate it through the first, second, fourth, and fifth phases. The second, third, and fourth phases in PBL develop students' abilities in writing scientific articles. The five phases of the PBL are expected to improve the quality of learning in Higher Education. Learning to use PBL is more meaningful, not just memorizing, and gathering information. PBL is learning that involves students to solve particular problem topics through scientific stages so that students can learn knowledge and have the ability to provide solutions in scientific papers (Schapper \& Mayson, 2010; Dewi et al, 2014; Untoro, 2016; Issufiah et al, 2018; Cheong et al, 2019; Imelda et al, 2019).

\section{Problem-solving Skills}

Problem-solving skills are one of the goals of learning in terms of curriculum aspects. The concepts in geography are related to daily life so that learning strategies based on problems are needed (Sujiono et al, 2017; Suwito et al, 2020). Geography learning is taught contextually according to the object of study. Contextual learning encourages the active role of students in developing and mastering concepts. Students can analyze in solving geographic problems that occur in everyday life.

The lack of student skills in solving problems will affect the quality of human resources (Cahyani \& Setyawati, 2016). The importance of improving the quality is as conveyed in the vision and mission of President Joko Widodo in the second period 2019-2024 (Kompasiana, 2019). It is because the process of acquiring geography has not yet maximized the model or learning steps that direct students to develop problem-solving skills. Lecturers are expected to be wiser in choosing models whose syntax allows students to gain knowledge independently through problem-based learning.

The use of appropriate learning models can improve student skills in problem solving. One of the learning models that can improve problem-solving skills is problem-based learning (Crebert et al, 2011; Dwi et al, 2013; Cheriani et al, 2015; Cahyani \& Setyawati, 2016; Kadir et al, 2016; Faudiah et al, 2018). Problem based learning is designed to help students develop their thinking, problem solving, and intellectual skills independently. Lecturers function as facilitators and motivators and planners in problem-based learning. Planners must have skills in designing geography learning that can not only develop students' understanding of concepts but also improve their thinking skills.

PBL Model direct students to solve problems by finding information based on reality in the field and then solving them. Write reports on the results of independent or group investigations in the field based on the rules of writing that are logical and systematic. Furthermore, students can explain and be responsible for these scientific articles in front of the class. Other than that, students are also required to have scientific writing skills, so that thesis writing runs smoothly. (Puspitasari, 2013; Wardani \& Sari, 2017). Therefore, the experience of research becomes an important matter for students before taking a thesis course. 


\section{Scientific Writing}

A scientific article is argumentative writing. Regarding the research process and writing research reports, scientific articles can be said to be "miniature" research reports. The purpose of writing scientific articles is a means of expressing ideas or thoughts, as well as the results of research through various scientific media, such as scientific journals, newspapers, or for dissemination or research seminar results. The technique of writing scientific articles is the same as the technique for writing research reports. The difference is that scientific articles are arranged more concisely (Marwoto et al, 2013). Some scientific works have been published, and some are not published. Published scientific works are called scientific articles, for example, scientific journals or magazines, proceedings, and books. Unpublished scientific works are research reports, field practice reports, theses, and dissertations.

The ability to write is an essential skill that students need to have. The benefits of students having the ability to write are: sharper imagination, mastery of language increases, and increase confidence (Oppenheimer et al, 2017; Yanti et al, 2018). Writing skill shows the quality of student learning. Therefore, these abilities must be improved through the learning process. Lecturers can design learning processes that lead to students' ability to write scientific articles through the selection of adequate models in learning.

The learning model is the steps of the activities in the learning process. Lecturers are professionally selective in using models to achieve planned learning goals. The selection of the right model can affect the achievement of learning objectives. The Problem Based Learning (PBL) learning model facilitates the ability to research through the second and third phases. The writing ability of students is facilitated through the fourth phase, followed by evaluating the results of the discussion and how to present articles. However, lecturer motivation is needed to improve students' writing skills as compensation for limitations that do not exist in the learning steps in PBL (Parra \& Calero, 2019).

\section{METHOD}

The research design uses a quasi-experiment with participants consisting of two natural resource (SDA) classes in the even semester of the academic year 2017/2018 of the Geography Education Study Program at Kanjuruhan University Malang, Indonesia. Selection of experimental and control groups based on the average score of the midterm exam in 4 classes that are almost the same. Class A, B, C, D average score are 85, 80, 75 and 88. Class A as control group consists of 30 students, while Class D as experiment group consists of 32 students. Control class and experiment class selection conducted by drawing using coins (Sugiyono, 2010).

The experiment group using problem-based learning model while control group using conventional models (lecture and book research). At this point, the judgement based on student skills in problem solving and the ability to write scientific articles individually. The treatment of learning in the two groups can be seen in table 2 . 
Table 2

Treatment design of problem-solving skill variable

\begin{tabular}{llll}
\hline Group & Pretest & Treatment & Posttest \\
\hline Experiment & $\mathrm{O}_{1}$ & $\mathrm{X}_{1}$ & $\mathrm{O}_{1}$ \\
Control & $\mathrm{O}_{2}$ & $\mathrm{X}_{2}$ & $\mathrm{O}_{2}$ \\
\hline
\end{tabular}

Information:

$\mathrm{X}_{1} \quad$ : Problem based learning model treatment

$\mathrm{X}_{2}$ : Without problem-based learning model treatment

$\mathrm{O}_{1} \quad$ : Result (problem-solving skills) of experiment group

$\mathrm{O}_{2} \quad$ : Result (problem-solving skills) of control group

The Treatment on scientific article writing skills variable is not using pretest but posttest only (Hidayat, 2012; Wardani \& Sari, 2017). The complete design explanation on table 3.

Table 3

Treatment design of scientific article writing skills variable

\begin{tabular}{lll}
\hline Group & Treatment & Post test \\
\hline Experiment & $\mathrm{X}_{1}$ & $\mathrm{O}_{1}$ \\
Control & $\mathrm{X}_{2}$ & $\mathrm{O}_{2}$ \\
\hline
\end{tabular}

Information:

$\mathrm{X}_{1} \quad$ : Problem based learning model treatment

$\mathrm{X}_{2} \quad$ : Without problem-based learning model treatment

$\mathrm{O}_{1} \quad$ : Result (scientific article writing skills) of experiment group

$\mathrm{O}_{2} \quad$ : Result (scientific article writing skills) of control group

The material of learning was the management of natural resources for human survival on Earth. Before conducting research, firstly, the semester learning plan and lesson plan were prepared. After that, their validity and reliability were tested.

\section{Instrument}

The instrument used were an essay test and a rubric assessment. Essay tests were used to measure students' skills in solving problems. The rubric was used to assess students' scientific writing skills. Essay tests consisted of five questions and had been tested for the level of difficulty, difference, validity, and reliability. The assessment rubric contained some indicators for scientific writing. Five aspects were assessed, namely: 1) format of the manuscript, 2) creativity of ideas, 3) the topics raised, 4) data and sources of information, and 5) analysis of synthesis sources of information.

\section{Data Collection}

Data collection was obtained from the results of the pretest and posttest, which assessed students' problem-solving skills. The degree of scientific writing skills was obtained from the assessment rubric. The article evaluation was done at the end of the lesson to score their writing skills. The data obtained were quantitative data of students' grades.

\section{Data Analysis}

Research data about problem solving skills and scientific articles writing skills of students on the PBL models are analyzed using parametric statistics. The use of 
parametric statistical analysis by fulfilling the prerequisite tests with normal distribution. The normality test uses the Kolmogorov-Smirnov test. If the data found is not normally distributed, non-parametric statistical analysis is used. The data were analyzed using SPSS version 23.0 for Windows.

\section{FINDINGS}

The results showed that the average gain score of problem-solving skills in the experimental group was 29.06, while the control class was 21.83 . The average value of the posttest score on writing scientific articles in the experimental class was 68.44 , while the control class was 63 , explained in table 4 . Initial data processing is done by prerequisite test, the normality at the 0.05 significance level using KolmogorovSmirnov.

Table 4

The result of pretest and post test

\begin{tabular}{lllll}
\hline Variables & Group & Average of Pretest & Average of Posttest & Gain Score \\
\hline \multirow{2}{*}{$\begin{array}{l}\text { Problem solving } \\
\text { skills }\end{array}$} & Experiment & 50,94 & 80,00 & 29,06 \\
\cline { 2 - 5 } $\begin{array}{l}\text { Writing scientific } \\
\text { skills }\end{array}$ & Control & 43,67 & 65,5 & 21,83 \\
\cline { 2 - 5 } & Experiment & - & 68,44 & - \\
\hline
\end{tabular}

Based on table 4, gain score is the difference between pretest and posttest score. Gain Score is used as hypothesis analysis material on problem-solving skills variable.

\section{Problem Solving Skills}

The prerequisite test of problem-solving skills showed that the data were not normally distributed $(\mathrm{p}=<0,05)$ as shown in table 5 .

Table 5

Normality test

\begin{tabular}{lllllll}
\hline \multirow{2}{*}{ Group } & \multicolumn{3}{l}{ Kolmogorov-Smirnov } & \multicolumn{4}{l}{ Shapiro-Wilk } \\
\cline { 2 - 7 } & Statistic & df & Sig. & Statistic & df & Sig. \\
\hline Experiment & .238 & 32 & .000 & .875 & 32 & .002 \\
\hline Control & .246 & & & & & \\
\hline
\end{tabular}

Based on table 5, the next step was to test the hypothesis using mann-whitney test analysis, explained in table 6.

Table 6

Mann-Whitney test

\begin{tabular}{llll}
\hline Mann-Whitney U & Wilcoxon W & Z & Asymp. Sig. (2-tailed) \\
\hline 235.000 & 700.000 & -3.535 & .000 \\
\hline
\end{tabular}

Result of mann-whitney test analysis shown p-level 0,000 smaller than 0,05 . This is mean that $\mathrm{HO}$ rejected and $\mathrm{Ha}$ accepted, so there is influence of problem-based learning model on problem solving skills.

\section{Scientific Writing Skills}

Scientific writing skills of experiment and control classes explained on table 7. 
Table 7

Scientific Writing Skills Distribution Score

\begin{tabular}{llllll}
\hline Group & N & Minimum & Maximum & Mean & Std. Deviation \\
\hline Experiment & 32 & 55 & 80 & 68.44 & 9.019 \\
\hline Control & 30 & 50 & 70 & 59.83 & 7.008 \\
\hline Valid N (listwise) & 30 & & & & \\
\hline
\end{tabular}

Mean distribution of scientific writing skills on table 7 shows that experiment class score is higher than control class. then tested the normality value of experiment and control class score posttest.

The results of the prerequisite test analysis of scientific writing skills indicate that the data distribution is not normal $(\mathrm{p}=>0,05)$, see table 8 .

Table 8

Normality test

\begin{tabular}{lllllll}
\hline \multirow{2}{*}{ Kelas } & \multicolumn{3}{l}{ Kolmogorov-Smirnov } & \multicolumn{4}{l}{ Shapiro-Wilk } \\
\cline { 2 - 7 } & Statistic & df & Sig. & Statistic & df & Sig. \\
\hline Eksperimen & .173 & 32 & .016 & .892 & 32 & .004 \\
\hline Kontrol & .162 & & & & & \\
\hline
\end{tabular}

Based on table 8, next step is to test the hypothesis using Mann-Whitney analysis test. See table 9.

Table 9

Mann-Whitney test

\begin{tabular}{llll}
\hline Mann-Whitney U & Wilcoxon W & Z & Asymp. Sig. (2-tailed) \\
\hline 324.000 & 789.000 & -2.227 & .026 \\
\hline
\end{tabular}

Mann-Whitney analysis test result gain p-level 0,026 smaller than 0,05, this is mean H0 rejected and Ha accepted. So, hypothesis test accepted, there is influence of problembased learning model on scientific writing skills.

Problem-based Learning Model and Problem-solving Skills Influence on Scientific Writing Skills

Table 10

Friedman test

\begin{tabular}{llll}
\hline $\mathrm{N}$ & Chi-Square & $\mathrm{df}$ & Asymp. Sig. \\
\hline 62 & 25.011 & 2 & .000 \\
\hline
\end{tabular}

Based on table 10, gained p-level 0,00 smaller than 0,005, H0 rejected and Ha accepted. This is mean hypothesis accepted, there is influence of problem-based learning model and problem-solving skills on scientific writing skills.

\section{DISCUSSION}

\section{Problem-solving Skills}

The results indicated the influence of problem-based learning on problem-solving skills. The advantage of problem-based learning in each syntax influences student skills in 
problem-solving (Cheriani et al, 2015; Kadir et al, 2016). The orientation to the problems, the first phase, enlightens students' thinking skills to find solutions. The problem-solving abilities of students learned using problem-based learning are better than conventional learning which consists of lectures, discussions, and assignments of inquiry through literature (Sahyar et al, 2017). PBL is an innovative model; its steps advance to active learning (Schapper \& Mayson, 2010; Balim et al, 2014). The model was developed to help students improve their thinking skills in solving problems.

The provision of problems related to natural resources material stimulates students' thinking skills. Problems provide opportunities to increase students' motivation (Amir, 2009). It indicates that the provision of problems provides motivation and challenges for students that guide to the discovery of solutions that demand critical thinking. Lecturers can teach problem-solving skills through the first phase of PBL (Nayazik et al, 2013). The second phase of PBL supports problem-solving through the active role of the lecturer in organizing student learning tasks. Problem-solving skills can be taught through problem-based learning models (Argaw et al, 2017). Experiment class student characteristics that is given problem-based learning model is more active and motivated to solve problem than control class.

The lecturer gives orientation to problems related to the natural resources material to students in the first phase. The first phase is the advantage of the PBL. Students are actively involved in activities to solve problems being solved in groups (Wahyudi et al, 2015). Through problem-solving, students learn to explore examples and then make hypotheses, describe, and draw conclusions (Crebert et al, 2011). The learning steps in PBL support independent, active, and critical student learning. Therefore, learning outcomes in classes using PBL models are better than conventional classes on problemsolving skills competency. Learning that can improve problem-solving skills is the one that allows the students to be active in analyzing, synthesizing, investigating, and doing assignments (Faudiah et al, 2018).

\section{Scientific Writing Skills}

Problem-based learning has a significant effect on students' ability to write scientific articles. The significance can be seen in the results of the Mann-Whitney test, 0,026, with differentiation on mean score and deviation standard at control and experiment class. Mean score on experiment class is higher than control class. That differentiation influenced by difference in treatment on the learning model that is used. The PBL has learning steps that can influence the ability to write articles, which is in the third and fourth phases, namely investigation and developing and presenting artifacts or exhibits (Tarhan, \& Acer-Sesen, 2013). Student creativity in finding data independently and in groups through direct observation and interviews makes it easy for students to write scientific articles (Schapper \& Mayson, 2010; Cheong et al, 2019). The writing ability of students increases after going through the stages of investigation or investigation, both individually and in groups (Imelda et al, 2019).

Writing ability requires time allocation and learning steps that can provide opportunities for students to write the results of investigations in the form of written products. Good 
writing is produced through a process of mentoring from the lecturer and students' collaboration (Untoro, 2016). In the learning process, students practice to-observe, summarize, study literature, and write reports (Bean, 2011). Writing produced by students refers to five determined aspects, namely (1) aspects of content, (2) organization, (3) grammar, (4) choice of words, and (5) spelling (Pitoyo et al, 2014). Thus, increasing scientific writing ability can be achieved through the use of learning models that guide to these competencies.

\section{The Effects of Problem Based Learning and Problem-solving Skills on Scientific Skills}

Understanding the problem is an important indicator of problem-solving skills that must be trained in learning. This is in accordance with the first steps of the PBL model, namely problem orientation to students (Tan, 2009; Sota, \& Karl, 2017). Problem orientation trains students in understanding a problem, formulating a solution, carrying out a solution according to plan, and checking again all steps (Downing et al, 2009). Students who have problem solving skills affect the way they think and write in making work in the form of scientific articles. There are differences in learning to write in students who have high and low-level thinking skills (Klimova, 2013). Lecturers have the task of planning learning in accordance with the abilities of students through the selection of learning models that can develop an idea into a scientific article writing (Borglin, 2012).

PBL models and problem-solving skills significantly influence students' ability to write scientific articles. Problem solving skills are one component of higher-level thinking (Carter et al, 2017). These skills train how to analyze problem situations and make decisions based on analysis. Students analyze the phenomena around them by revealing evidence and reasons so that they can provide solutions in accordance with the information and knowledge they get through the investigation process in PBL learning (Belland et al, 2010; Suntusia et al, 2019). The process of analyzing and solving problems directs and strengthens students in writing articles through research activities. The ability to write scientific articles starts from the idea of students analyzing existing phenomena based on problems given by lecturers (Marni et al, 2019). Problem solving skills affect the ability to write to students (Shahsavar \& Shokrpour, 2016). Understanding the problem is an essential indicator of problem-solving skills that must be enlightened in learning. It is following the first steps of problem-based learning, namely problem orientation (Tan, 2009; Sota, \& Karl, 2017). Problem orientation guides students in understanding a problem, formulating a solution, carrying out a solution according to plan, and rechecking all steps (Downing et al, 2009). Problemsolving skills affect the way students think and write scientific articles. There are differences in learning to write for students who have high and low-level thinking skills (Klimova, 2013). Lecturers should plan learning following the abilities of students through the selection of learning models that can develop an idea into a scientific article (Borglin, 2012).

Problem-based learning and problem-solving skills significantly influence students' ability to write scientific articles. Problem-solving skills are one component of higher- 
level thinking (Carter et al, 2017). These skills develop how to analyze the problem and make decisions based on the results of the analysis in groups or independently. Students analyze the phenomena around them by revealing evidence and reasons so that they can provide solutions under the information and knowledge they get through the investigation process in PBL learning (Belland et al, 2010; Suntusia et al, 2019). The process of analyzing and solving problems points and strengthens students in writing articles through research activities. The ability to write scientific articles starts from the idea of students analyzing existing phenomena based on problems given by lecturers (Marni et al, 2019). Problem-solving skills affect the ability to write to students (Shahsavar \& Shokrpour, 2016).

\section{CONCLUSION}

The results showed 1) there was an effect of problem-based learning on students' problem-solving skills, 2) there was an effect of problem-based learning models on the ability to write scientific articles, and 3) there was an effect between problem based learning and problem-solving skills on the ability in writing scientific articles. The gain score differentiation between experimental and control classes on the problem-solving skills variable was 29.06 and 21.83 , while the average score on the ability to write scientific articles in experimental and control classes was 68,44 and 63,00.

Referring to the difference in the average value of posttest variables writing scientific articles in the experimental and control classes was 5,44. Therefore, need improvement efforts that must be made through the use of models with learning syntax oriented towards writing skills.

It is recommended to use a learning syntax model directing students to the ability to write scientific articles, namely the PGBR. Research-Based Geography Learning Model (PGBR) was developed by having specific learning steps to improve students' abilities in writing scientific articles. The ability to write articles is very necessary in learning at the university as a means for students to write ideas or solutions to problems related to the phenomenon of geography.

\section{REFERENCES}

Aliman, M. Budijanto., Sumarmi., \& Astina, I. K. (2019). Improving Environmental Awareness of High School Students' in Malang City through Earthcomm Learning in the Geography Class. International Journal of Instruction, 12(4), 79-94.

Alrahlah, A. (2016). How Effective the Problem Based Learning (PBL) in Dental Education. A Critical Review. The Saudi Dental Journal, 28, 155-161.

Amir, M. Taufik. (2009). Inovasi Pendidikan Melalui Problem Based Learning. Jakarta: Prenada Media Group.

Argaw, Aweke Shishigu., Haile, Beyene Bashu., Ayalew, Beyene Tesfaw., \& Kuma, Shiferaw Gadisa. (2017). The Effect of Problem Based Learning (PBL) Instruction on Students' Motivation and Problem-Solving Skills of Physics. EURASIA Journal of Mathematics Science and Technology Education, 13(3), 857-871. 
Arrends, R.I. (2008). Learning to Teach. Sixth Edition. New York: McGraw-Hill.

Asyari, M., Al Muhdhar, M. H. I., Susilo, H., \& Ibrohim. (2016). Improving Critical Thinking Skills Through the Integration of Problem Based Learning and Group Investigation. International Journal for Lesson and Learning Studies, 5(1), 36-44.

Balim, A. G., Turkoguz, S., Ormanci, U., Kacar, S., Evrekli, E., \& Ozcan, E. (2014). Teachers' Views about Problem Based Learning Through Concept Cartoons. Journal of Baltic Science Education, 13(4), 458-468.

Bean, J. C. (2011). Engaging Ideas: The Professor's Guide to Integrating Writing, Critical Thinking, and Active Learning in the Classroom. John Wiley \& Sons.

Belland, B. R., Glazewski, K. D., \& Richardson, J. C. (2010). Problem Based Learning and Argumentation: Testing a Scaffolding Framework to Support Middle School Students' Creation of Evidence Based Arguments. Instructional Science, 39(5), 667694.

Borglin, G. (2012). Promoting Critical Thinking and Academic Writing Skills in Nurse Education. Nurse Education Today, 32(5), 611-613.

Cahyani, Hesti., \& Setyawati, Ririn Wahyu. (2016). Pentingnya Peningkatan Kemampuan Pemecahan Masalah melalui PBL untuk Mempersiapkan Generasi Unggul Menghadapi MEA [The Importance of Developing Problem-Solving Skills through PBL to Prepare a Superior Generation for MEA]. Makalah disajikan dalam Seminar Nasional Matematika X Universitas Negeri Semarang, 29 Oktober.

Carter, A. G., Creedy, D. K., \& Sidebotham, M. (2017). Critical Thinking Evaluation in Reflective Writing: Development and Testing of Carter Assessment of Critical Thinking in Midwifery (Reflection). Midwifery, 54, 73-80.

Cheong, C. M., Zhu, X., Li, G. Y., \& Wen, H. (2019). Effects of Intertextual Processing on L2 Integrated Writing. Journal of Second Language Writing, 44, 63-75.

Cheriani, et al. (2015). Problem Based Learning Buginese Cultural Knowledge Model Case Study: Teaching Mathematics at Junior High School. International Education Studies; Vol. 8, No. 4.

Crebert, et al. (2011). Problem Solving Skills Toolkit, 2nd Edition. Griffith: Griffith University.

Dafik., Sucianto, B., Irvan, M., \& Rohim, M. A. (2019). Using Group Drawings Activities to Facilitate the Understanding of the Systemic Aspects of Projects. International Journal of Instruction, 12(4), 593-610.

Dewi, P.S.U., Sadia, I.W., \& Suma, K. (2014). Effect of Problem Based Learning Model of the Physics Problem Solving Ability Through Talent Numerical Control Junior High School Students. Journal Program Pascasarjana Universitas Pendidikan Ganesha Program Studi IPA, 4, 1-11. 
Downing, K., Kwong, T., Chan, S.W., Lam, T.-F., \& Downing, W.K. (2009). Problem Based Learning and the Development of Metacognition. Higher Education, 57(5), 609621.

Dwi, I.M., Arif, H., \& Sentot, K. (2013). Effect of Problem Based Learning Model to Understanding Concepts and Problem Solving Abilitys. Jurnal Pendidikan Fisika Indonesia, 8-17.

Dwyer, C. P., Hogan, M. J., \& Stewart, I. (2014). An Integrated Critical Thinking Framework for the 21st Century. Thinking Skills and Creativity, 12, 43-52.

Fajrianthi., Hendriani, W., \& Septarini, B. G. (2016). Pengembangan Tes Berpikir Kritis dengan Pendekatan Item Response Theory [Development of Critical Thinking Tests with the Item Response Theory Approach]. Jurnal Penelitian dan Evaluasi Pendidikan, 20(1), 45-55.

Faudiah, Ilah Solehati., Nurlaelah, Ilah., \& Setiawati, Ina. (2018). Application of Poblem Based Learning (PBL) on Problem Solving Abilities in Terms of Students Reasoning. Quagga, 10(1), 42-48.

Gholami, M., Moghadam, P. K., Mohammadipoor, F., Tarahi, M. J., Sak, M., Toulabi, T., \& Pour, A. H. H. (2016). Comparing the Effects of Problem Based Learning and the Traditional Lecture Method on Critical Thinking Skills and Metacognitive Awareness in Nursing Students in a Critical Care Nursing Course. Nurse Education Today, 45, 16-21.

Hidayah, Ratna., Salimi, Moh., \& Susiani, Tri Saptuti. (2017). Critical Thinking Skill: Konsep dan Indikator Penilaian [Critical Thinking Skill: Concepts and Indicators of Assessment]. Jurnal Taman Cendekia, 1(2), 127-133.

Hidayat, Anwar. (2012). Penelitian Eksperimen. (Online), (https://www.statistikian.com/2012/10/penelitian-experimen.html, diakses pada tanggal 19 Juni 2020).

Hosnan, M. (2014). Pendekatan Saintifik dan Kontekstual dalam Pembelajaran Abad 21 Kunci Sukses Implementasi Kurikulum 2013 [Scientific and Contextual Approaches in 21st Century Learning: The Key to Successful Implementation of the 2013 Curriculum]. Bogor: Ghalia Indonesia.

Imelda., Cahyono, B. Y. \& Astuti, U. P. (2019). Effect of Process Writing Approach Combined with Video-Based Mobile Learning on Indonesian EFL Learners' Writing Skill Across Creativity Levels. International Journal of Instruction, 12(3), 325-340.

Issufiah, D. N., Sunardi., Sri, A. W., \& Gunarhadi. (2018). The Implementatyion of Problem Based Learning Model (PBL) on Teachers and Students Grade Five Elementary Schools in Surakarta City. International Journal of Active Learning, 3(2), 116-123.

Kadir, Z.A., Abdullah, N.H., Anthony, E., Mohd Salleh, B., \& Kamarulzaman, R. (2016). Does Problem Based Learning Improve Problem Solving Ability? A Study 
Among Business Undergraduates at Malaysian Premier Technical University, International Education Studies, 9(5). 166-172.

Klimova, B. F. (2013). Developing Thinking Skills in the Course of Academic Writing. Procedia Social and Behavioral Sciences, 93, 508-511.

Kompasiana. 17 Agustus 2019. SDM Unggul, Indonesia Maju? Mudah-mudahan Bukan Slogan Kosong Belaka [Excellent HR, Indonesia Advanced? Hopefully Not Just a Blank Slogan], hlm. $\quad 1, \quad$ (Online), (https://www.kompasiana.com/hamdalianton/5d5816bf0d823025e161cb62/sdm-unggulindonesia-maju-mudah-mudahan-bukan-slogan-kosong-belaka?page=all), diakses 8 Desember 2019.

Marni, S., Suyono, Roekhan., \& Harsiati, T. (2019). Critical Thinking Patterns of First Year Students in Argumentative Essay. Journal for the Education of Gifted Young Scientists, 7(3), 683-697.

Marwoto, Putut., Sopyan, Achmad., Linuwih, Suharto., \& Subali, Bambang., \& Ellianawati. (2013). Peningkatan Kemampuan Menulis Artikel Ilmiah Sains Guru Sekolah Dasar Melalui Kegiatan Pengabdian Masyarakat [Enhancing the Ability to Write Scientific Articles of Elementary School Teachers Through Community Service Activities]. ABDIMAS, 17(2), 111-116.

Nayazik, Akhmad. (2017). Pembentukan Keterampilan Pemecahan Masalah melalui Model IDEAL Problem Solving dengan Teori Pemrosesan Informasi [Formation of Problem-Solving Skills through the IDEAL Problem-Solving Model with Information Processing Theory]. Jurnal Matematika Kreatif-Inovatif (Kreano), 8(2), 182-190.

Nayazik, A., Sukestiyarno, S., \& Hindarto, N. (2013). Peningkatan Karakter dan Pemecahan Masalah Melalui Pembelajaran IDEAL Problem Solving-Pemrosesan Informasi [Enhancement of Character and Problem-Solving Skill Through IDEAL Problem Solving-Information Processing Learning]. Unnes Journal of Mathematics Education Research, 2(2). Retrieved.

Oppenheimer, D., Zaromb, F., Pomerantz J. R., Wiliams, J. C., \& Park, Y. S. (2017). Improvement of Writing Skills During College: A Multi Year Cross Sectional and Longitudinal Study of Undergraduate Writing Performance. Assessing Writing, 32, 1227.

Parra G. L., \& Calero S. X. (2019). Automated Writing Evaluation Tools in the Improvement of the Writing Skill. International Journal of Instruction, 12(2), 209-226.

Pitoyo, Andri., Waluyo, Herman J., Suwandi., Sarwiji., \& Andayani. (2014). The Effect of PBL Learning Model, Accelerated Learning Team and Role Playing on Elementary School Students' Writing Skills Viewed from Cognitive Style. Journal of Education and Practice, 5(1), 21-29. 
Puspitasari, R.T. (2013). Adversity Quotient dengan Kecemasan Mengerjakan Skripsi pada Mahasiswa [Students' Adversity Quotient and Anxiety in Working Thesis]. Jurnal Online Psikologi, 1(2), 299-310.

Redhana, I Wayan. (2019). Mengembangkan Keterampilan Abad Ke 21 dalam Pembelajaran Kimia [Developing 21st Century Skills in Chemistry Learning]. Jurnal Inovasi Pendidikan Kimia, 13(1), 2239-2253.

Sahyar., Sani, Ridwan A., \& Malau, Tionar. (2017). The Effect of Problem Based Learning (PBL) Model and Self-Regulated Learning (SRL) Toward Physics Problem Solving Ability (PSA) of Students at Senior High School. American Journal of Educational Research, 5(3), 279-283.

Saputra, Maskhur Dwi., Joyoatmojo, Soetarno., Wardani, Dewi Kusuma., \& Sangka, Khresna Bayu. (2018). Developing Critical Thinking Skills Through the Collaboration of Jigsaw Model with Problem Based Learning Model. International Journal of Instruction, 12(1), 1077-1094.

Sari, Rima Meilita., Sumarmi., Astina, I Komang., Utomo, Dwiyono Hari., \& Ridhwan. (2019). Measuring Students Scientific Learning Perception and Critical Thinking Skill Using Paper-Based Testing: School and Gender Differences. International Journal of Emerging Technologies in Learning (iJET), 14(19), 132-149.

Schapper, J., \& Mayson, E. S. (2010). Research-led Teaching: Moving from a Fractured Engagement to a Marriage of Convenience. Higher Education Research \& Development, 29(2), 641-651.

Shahsavar, Zahra., \& Shokrpour, Nasrin. (2016). The Effects of Applying Critical Thinking Skills on EFL Medical Students' Argumentative Writing, The Global Elearning Journal, 5(2), 1-5.

Sota, C., \& Karl, P. (2017). The Effectiveness of Research Based Learning Among Master-Degree Student for Promotion and Preventable Disease, Faculty of Public Health, Khon Kaen University, Thailand. International Conference on intercultural Education, Health and ICT for a Transcultural Word, EDUHEM, 19(4), 725-737.

Sugiharto, B., Corebima, A. D., Susilo, H., \& Ibrohim. (2019). The Pre-Service Biology Teacher Readiness in Blended Collaborative Problem Based Learning (BCPBL). International Journal of Instruction, 12(4), 113-130.

Sugiyono. (2010). Metode Penelitian Kuantitatif, Kualitatif dan R \& D. Bandung: Alfabeta.

Sujiono., Handoyo, Budi., \& Ruja, I Nyoman. (2017). Memecahkan Masalah Geografi Melalui Problem Based Learning. [Solving Geography Problems Through Problem Based Learning]. Jurnal Teori dan Praksis Pembelajaran IPS, 2(2), 14-20.

Suntusia, Dafik., \& Hobri. (2019). The Effectiveness of Research Based Learning in Improving Students' Achievement in Solving Two-Dimensional Arithmetic Sequence Problem. International Journal of Instruction, 12(1), 17-32. 
Sutarman., Sunendar, D., \& Mulyati, Y. (2019). Investigating Cooperative Learning Model Based on Interpersonal Intelligence on Language Learners Skill to Write Article. International Journal of Instruction, 12(4), 201-218.

Suwito., Budijanto., Handoyo, B., \& Susilo, S. (2020). The Effects of 5E Learning Cycle Assisted with Spatial Based Population Geography Textbook on Students' Achievement. International Journal of Instruction, 13(1), 315-324.

Tan, O. S. (2009). Problem Based Learning and Creativity. Singapore: Cengage Learning Asia Pte Ltd.

Taradi, S. K., Taradi, M., Radić, K., \& Pokrajac, N. (2005). Blending problem-based learning with web technology positively impacts student learning outcomes in acid-base physiology. Advances in Physiology Education, 29(1), 35-39.

Tarhan, L., \& Acar-Sesen, B. (2013). Problem Based Learning in Acids and Bases: Learning Achievements and Students' Beliefs. J. of Baltic Science Educ, 12(5), 565578.

Untoro, Bambang. (2016). The Effect of Group Investigation and Learning Style on Students' Writing of Analytical Exposition. IJEE (Indonesian Journal of English Education), 3(1), 29-45.

Wahyudi., Sugiharto, B., \& Widoretno, S. (2015). Upaya Meningkatkan Kemampuan Komunikasi Oral Siswa Melalui Penerapan Model Pembelajaran Problem Based Instruction Siswa Kelas VII-A SMP Negeri 22 Surakarta Tahun Pelajaran 2012/2013 [Efforts to Improve Students' Oral Communication Skills Through the Application of Problem Based Learning for VII-A Grade Students of SMP Negeri 22 Surakarta in the 2012/2013 Academic Year]. Bio-Pedagogi, 4(1), 30-35.

Wardani, Nila Restu., \& Sari, Yuli Ifana. (2017). Pengaruh Model Group Investigation Terhadap Kemampuan Menulis Artikel Mahasiswa [The Influence of Group Investigation Model on Students' Ability to Write Articles]. Jurnal Pendidikan dan Ilmu Geografi, 2(1), 160-166.

Widiawati, L., Joyoatmojo, S., \& Sudiyanto. (2018). Higher Order Thinking Skills as Effect of Problem Based Learning in the 21st Century Learning. International Journal of Multicultural and Multireligious Understanding, 5(3), 96-105.

Yanti, Nafri., Suhartono., \& Hiasa, Fina. (2018). Keterampilan Menulis Akademik Mahasiswa S-1 Program Studi Pendidikan Bahasa dan Sastra Indonesia FKIP Universitas Bengkulu [Academic Writing Skills of S-1 Students of the Indonesian Language and Literature Education in FKIP Bengkulu University]. Silampari Bisa: Jurnal Penelitian Pendidikan Bahasa Indonesia, Daerah, dan Asing, 1(1), 1-16. 